\title{
Antioxidant Role of Kaempferol in Prevention of Hepatocellular Carcinoma
}

\author{
Nidhi Sharma $^{1}$, Subhrajit Biswas ${ }^{2}\left(\right.$, , Noura Al-Dayan ${ }^{3}{ }^{(0)}$, Alaa Saud Alhegaili ${ }^{3(\mathbb{C}}$ and Maryam Sarwat ${ }^{1, *(1)}$ \\ 1 Amity Institute of Pharmacy, Amity University, Noida 201313, Uttar Pradesh, India; nidhi13995@gmail.com \\ 2 Amity Institute of Molecular Medicine \& Stem Cell Research, Amity University, Noida 201313, Uttar Pradesh, \\ India; sbiswas2@amity.edu \\ 3 Medical Laboratory Department, Applied Medical Science, Prince Sattam bin Abdul Aziz University, \\ Al-Kharj 16278, Saudi Arabia; n.aldayan@psau.edu.sa (N.A.-D.); a.alhegaili@psau.edu.sa (A.S.A.) \\ * Correspondence: msarwat@amity.edu
}

check for updates

Citation: Sharma, N.; Biswas, S.; Al-Dayan, N.; Alhegaili, A.S.; Sarwat, M. Antioxidant Role of Kaempferol in Prevention of Hepatocellular Carcinoma. Antioxidants 2021, 10, 1419. https://doi.org/10.3390/ antiox10091419

Academic Editors: Kavindra

Kumar Kesari, Dhruv Kumar, Niraj Kumar Jha and Janne Ruokolainen

Received: 14 June 2021

Accepted: 3 September 2021

Published: 5 September 2021

Publisher's Note: MDPI stays neutral with regard to jurisdictional claims in published maps and institutional affiliations.

Copyright: (c) 2021 by the authors. Licensee MDPI, Basel, Switzerland. This article is an open access article distributed under the terms and conditions of the Creative Commons Attribution (CC BY) license (https:// creativecommons.org/licenses/by/ $4.0 /)$.

\begin{abstract}
Reactive oxygen species (ROS) are noxious to cells because their increased level interacts with the body's defense mechanism. These species also cause mutations and uncontrolled cell division, resulting in oxidative stress (OS). Prolonged oxidative stress is responsible for incorrect protein folding in the endoplasmic reticulum (ER), causing a stressful condition, ER stress. These cellular stresses (oxidative stress and ER stress) are well-recognized biological factors that play a prominent role in the progression of hepatocellular carcinoma (HCC). HCC is a critical global health problem and the third leading cause of cancer-related mortality. The application of antioxidants from herbal sources significantly reduces oxidative stress. Kaempferol (KP) is a naturally occurring, aglycone dietary flavonoid that is present in various plants (Crocus sativus, Coccinia grandis, Euphorbia pekinensis, varieties of Aloe vera, etc.) It is capable of interacting with pleiotropic proteins of the human body. Efforts are in progress to develop KP as a potential candidate to prevent HCC with no adverse effects. This review emphasizes the molecular mechanism of KP for treating HCC, targeting oxidative stress.
\end{abstract}

Keywords: free radicals; oxidative stress; HCC; anti-oxidants; ER stress; kaempferol

\section{Introduction}

Kaempferol is a yellow-colored dietary flavonoid, present in numerous fruits and vegetables including apples (Malus domestica), aloe (Aloe vera), beans (Phaseolus vulgaris), broccoli (Brassica oleracea), carrot (Daucus carota), gooseberry (Ribes uva-crispa), strawberries (Fragaria $\times$ ananassa), saffron (Crocus sativus), tea (Camellia sinensis), and honey (Apis mellifera) [1-5]. It is a tetrahydroxyflavone that has hydroxy groups located at positions 3 , 5, 7, and 40 [6]. Kaempferol and its glycosylated derivatives are found to possess cardioprotective [7], neuroprotective [8], anti-inflammatory [4], antidiabetic [9], antioxidant [10], antimicrobial, [11] and anti-cancer activities [12,13] (Figure 1). Kaempferol gets absorbed by the small intestine due to its lipophilicity [14] or either by passive absorption, facilitated diffusion, or active transport [15]. Kaempferol, being a polyphenolic neutraceutical compound, exhibits high cytotoxicity, and thus has a promising role in cancer therapy. It has been demonstrated to invoke several mechanisms in the regulation of cancer cells. Cancer prevention is largely accomplished by inducing apoptosis, inhibiting cell proliferation [16], and promoting cell cycle arrest mainly in the G2/M phase [17]. Researchers have reported that kaempferol reduces cell viability and proliferation in the lungs [18], and colorectal cancer [19]. It inhibits the cell viability in HCC in a dose- and time-dependent manner [20]. Epidemiological data showed that a good intake of kaempferol is connected with low incidences of liver cancer [21]. Encouragingly, a kaempferol-rich diet has reduced the risk of cancer in smokers [22]. It has proved to be a better candidate molecule in increasing the efficacy of other anticancer drugs. Kaempferol, in combination with sorafenib (at 
subtoxic concentration), enhances the efficacy of sorafenib chemotherapy [23]. It is a potent scavenger of ROS that works by reducing cellular oxidative stress [24]. It augments the antioxidant potential of normal cells via modulating heme oxygenase (HO)-1 expression and mitogen-activated protein kinase (MAPK) pathways [25]. The HO-1 is a redox-sensitive inducible enzyme whose overexpression enhances cell resistance to oxidative injury.

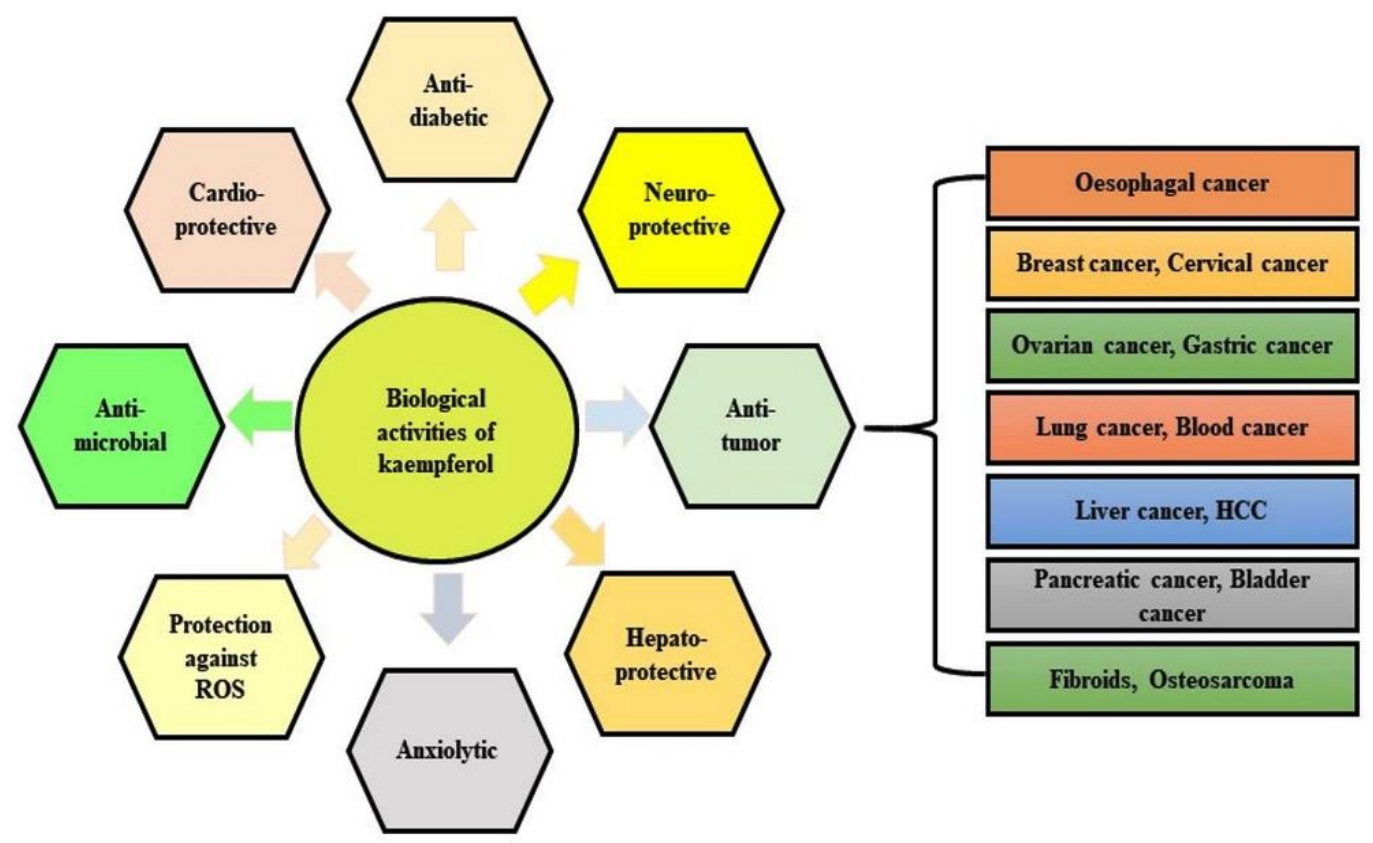

Figure 1. Pharmacological activities of kaempferol.

Free radicals are moieties with one or more unpaired electron in atomic or molecular orbitals formed during a variety of biochemical reactions and cellular functions [26]. ROS are the active metabolites of healthy cells, which include free radicals such as superoxide $\left(\mathrm{O}_{2}{ }^{-}\right)$and hydroxyl radical $\left(\mathrm{OH}^{\bullet}\right)$, as well as nonradical species, such as hydrogen peroxide $\left(\mathrm{H}_{2} \mathrm{O}_{2}\right)$ [27]. The sequential reduction of oxygen leads to the genesis of these species. The physiological concentration of ROS is essential in carrying out vital cellular processes including proliferation, apoptosis, cell cycle arrest, and cell senescence, whereas high ROS flux damages cell macromolecules including proteins, lipids, and nucleic acids (DNA and RNA) [28]. Therefore, the smooth conduction of all metabolic functions requires a balanced redox state. Overproduction of ROS due to endogenous (e.g., mitochondria, peroxisomes, and oxygen-handling enzymes) and exogenous reactions (e.g., UV, heavy metals, and micronutrients) or inefficient/exhausted antioxidants leads to oxidative stress [27]. It may lead to the development of various chronic diseases such as cardiovascular diseases [29,30], neurodegenerative diseases [31,32], allergy [33], and carcinogenesis [34].

HCC is the most lethal type of cancer, and is the third leading cause of cancer-related mortality worldwide $[35,36]$. Risk factors such as hepatitis B virus (HBV), hepatitis C virus (HCV), aflatoxin-contaminated food, cirrhosis, diabetes mellitus, obesity, alcohol abuse, smoking, and non-alcoholic fatty liver diseases (NAFLD) are involved directly and indirectly in the pathogenesis of HCC $[37,38]$. Management of HCC patients depends on the stage of the tumor. Surgery is the main curative therapy for HCC, but there are very high chances of tumor recurrence in patients with HCC [39]. The treatment options comprise repeated liver resection, transarterial therapy, ablative therapy, and systemic medical therapies [40]. A recent study proposed the beneficial role of salvage liver transplant in treating HCC recurrence, but this remains controversial due to organ shortage and the overall low rate of patients that may fulfill transplant criteria at the time of recurrence [41]. Many scientists have reported the better long-term effects of redo surgery over thermoablation. Palliative treatment of HCC includes trans-arterial 
chemo-embolization (TACE), targeted molecular therapy, and systemic medical therapies such as Sorafenib treatment, etc. [42]. HCC is a multi-stage process that involves various complex pathways in its pathogenesis, including RAF/ERK/MAPK, PI3K/Akt/Mtor, Ras and JAK-STAT, Wnt- and RB1-dependent signaling cascade [43]. However, oxidative stress emerged as a key player in the development and progression of HCC [44]. Dysregulation of ROS-producing and ROS-scavenging enzymes contributes to the development of HCC leading to poor patient survival. This review summarizes the mechanism of the antioxidant potential of kaempferol in treating HCC.

\section{Regulated Cell Death and Kaempferol}

Regulated cell death (RCD) is beneficial in maintaining the organism's hemostasis. Autophagy and apoptosis are the two important parts of RCD [45]. Autophagy is an evolutionary conserved cellular process targeting the damaged cells and organelles in lysosomal degradation. Autophagy is induced in response to the metabolic crisis and damaged organelles [46]. Apoptosis, or programmed cell death, governs the autonomous removal of infected and damaged cells. Activation and suppression of the two arms of RCD (apoptosis and autophagy) have been suggested as methods for curing liver cancer, including HCC [47-50]. Several hypotheses have been considered regarding the antitumor potential of kaempferol via RCD. Kaempferol is reported to induce autophagic cell death against SK-Hep1 (human hepatic cancer cell line) via AMPK and AKT signaling pathways [17]. Kaempferol inhibits cell proliferation, metastasis, invasion and induces apoptosis in HepG2 liver cancer cells by reducing the expression of miRNA [51]. Kaempferol, in combination with luteolin, induces apoptosis and causes cell cycle arrest at the G2/M phase, thus preventing cell migration and invasion [14].

\section{Oxidative Stress (OS) in Hepatocarcinogenesis}

Various mechanisms involved in hepatocarcinogenesis include the attenuation of tumor suppressor function, oncogene activation, and oxidative stress [52].

Oxidative stress could be promoted by any dangerous or inflammatory signal which damages hepatocytes, promotes pathological polyploidization, and triggers inflammation [53]. Increased levels of ROS and oxidative stress promote genetic and epigenetic alterations which contribute to the regulation of onco-suppressor, onco-promoter, and several proinflammatory genes involved in the development of HCC [54]. Additionally, they also promote the migration, invasion, and metastasis of HCC for different etiologies [55]. More the $80-90 \%$ of HCC cases are associated with chronic hepatic inflammation, non-alcoholic steatohepatitis (NASH), and hepatitis B virus (HBV), and hepatitis C virus (HCV) [56].

In the hepatocytes, ROS cause the activation of several cellular pathways including mitogen-activated protein kinase (MAPK), nuclear factor-kB (NF-kB), phosphatidylinositol 3- kinase (PI3K), p53, b-catenin/Wnt, and angiogenesis. Notably, these pathways play a vital role in mutagenesis, tumor promotion, and progression [57], and for this reason, oxidative stress has a strong connection with hepatocarcinogenesis.

\subsection{HBV and HCV Related HCC and Oxidative Stress}

Chronic HBV and HCV infection are often associated with the development of cirrhosis, and HCC [58]. These unrelated viruses belong to two different viral families and exhibit strong hepatotropism, but their molecular mechanism to produce HCC is still under investigation. Some researchers have found that the viral encoded proteins alter the cellular phenotype and host gene expression, which is the hallmark of cancer [59]. HBVand HCV-related fibrosis and chronic inflammation of the liver are induced by OS, which eventually contributes to the development of HCC. HBV infection leads to the activation of macrophages or Kupffer cells to produce proinflammatory cytokines, including IL-1 $\beta$, IL-6, and TNF- $\alpha$ [60]. Irregular cytokine generation and ROS production have an influential role in hepatocarcinogenesis. The HBV genome encodes a variety of gene products, including 
a multifunctional HBx protein, which has carcinogenic potential. This protein promotes replication of the virus and protects the virus-infected cells from damage [61]. This process takes place in hepatocytes only, which further progresses to HCC [62].

Genetic mutations found in the samples from HBV patients have a strong correlation with the initiation and development of liver cancer [63]. Recent studies proved that the mutant genes and their products accumulate in the endoplasmic reticulum (ER) and promote carcinogenesis through ER stress and ROS production. On the other hand, during HCV infection, immunomodulatory molecules such as programmed cell death protein ligand-1 (PD-L1) become activated, affecting inflammatory signaling pathways. Continuous inflammation leads to the development of HCC via PKR, STAT3, and TNFR pathways [64]. Moreover, serological markers and iron accumulation are usually elevated during chronic $\mathrm{HCV}$ infection, and excessive bivalent iron is strongly toxic, leading to the induction of Fenton's reaction and ROS [65]. Thus, oxidative stress plays an important role in HBV- and HCV-related liver cancer development.

\subsection{Non-Alcoholic Steatohepatitis (NASH) Related HCC and OS}

NASH is a chronic liver injury causing steatosis, inflammation, and progressive fibrosis, ultimately leading to cirrhosis and HCC [66]. As proposed by Day and James, the pathogenesis of NASH is a two-hit theory [67]. The first hit includes the progression of steatosis, correlated with the accumulation of triglycerides in the liver cells. The second hit includes a wide variety of cellular stress factors, e.g., gut-derived stimulation, intestinal circumstances, apoptosis, oxidative stress, and ER stress, etc. [68]. Overconsumption of carbohydrates or saturated fatty acids and less polyunsaturated fatty acids leads to lipid accumulation in hepatocytes. The adipose tissues release adiponectin, resistin, and tumor necrosis factor-alpha (TNF- $\alpha$ ), leading to inflammation of the cells, induction of mitochondrial destruction, and ROS generation [69]. Among the above-mentioned factors, adiponectin is a fat factor that modulates cell proliferation, inhibits cancer cell growth, metastasis [70], and induces apoptosis [71]. Oxidative stress is an important process regulated by the 1L-17 protein, whose receptors are widely distributed on the surface of liver cells. Patients with an elevated level of serum IL-17 have a higher risk of early recurrence of liver cancer after surgery [72]. ROS are the metabolic by-products in hepatocytes generated due to elevated mitochondrial fatty acid oxidation and inadequate mitochondrial respiratory chain activity. The ROS level tends to increase in NASH [73] and results in the disruption of hepatic fatty acid homeostasis and accumulates non-metabolized fatty acids in the cytoplasm [74]. Thus, oxidative stress is a harmful key component causing the progression of NASH to HCC. The mechanism of oxidative stress in $\mathrm{HBV}, \mathrm{HCV}$, and NASH-related HCC is summarized in Table 1.

Table 1. Role of oxidative stress on HCC and associated diseases.

\begin{tabular}{|c|c|c|c|c|}
\hline Cause & Factors Activated & Mechanism Involved & $\begin{array}{l}\text { Impact on Oxidative } \\
\text { Stress and HCC }\end{array}$ & References \\
\hline \multirow[t]{2}{*}{$\begin{array}{c}\text { Hepatitis B Virus } \\
\text { (HBV) }\end{array}$} & HBx protein & $\begin{array}{c}\uparrow \text { Oncogene expression, } \\
\text { activation of macrophages to release } \\
\text { proinflammatory cytokines (IL- } 1 \beta \text {, IL-6, } \\
\text { CXCL-8, and TNF- } \alpha \text { ), activation of apoptosis }\end{array}$ & \multirow[t]{2}{*}{$\uparrow$ ROS and HCC } & \multirow[t]{2}{*}{ [61] } \\
\hline & Gene mutation & Induce ER stress & & \\
\hline \multirow[t]{2}{*}{$\begin{array}{c}\text { Hepatitis C Virus } \\
\text { (HCV) }\end{array}$} & Core Protein & $\begin{array}{l}\text { Activates signaling pathways (TNFR, PKR, } \\
\text { and STAT3 pathways), induces apoptosis, } \\
\text { metastasis, and DNA damage. }\end{array}$ & \multirow[t]{2}{*}{$\uparrow$ ROS and HCC } & \multirow[t]{2}{*}[64,75]{} \\
\hline & $\mathrm{Fe} 2+$ accumulation & Fenton reaction (Iron toxicity) & & \\
\hline \multirow[b]{2}{*}{ NASH } & Fatty toxicity & $\uparrow$ IL-17 & \multirow[b]{2}{*}{$\uparrow$ ROS and HCC } & \multirow[b]{2}{*}{ [71] } \\
\hline & Central Obesity & $\begin{array}{l}\text { Reduces the level of adiponectin, leading to } \\
\text { increased cell growth, proliferation, and } \\
\text { metastasis }\end{array}$ & & \\
\hline
\end{tabular}




\section{Antioxidant Potential of Kaempferol in Preventing HCC}

Kaempferol possesses a remarkable spectrum of pharmacological activities, including antidepressant, anxiolytic, anti-inflammatory, antitumor, etc. [76,77]. Researchers have indicated the antioxidant potential of kaempferol in both in vitro and in vivo models [78]. It causes the scavenging of the free radicals and other ROS molecules, as their generation transforms the normal cells into malignant ones [79]. So, inhibition of these species alters the tumor cell phenotype. Kaempferol pre-treatment of $\mathrm{CCl}_{4}$ challenged mice showed normalized activities of liver enzymes [80]. Further, kaempferol 3-O- $\beta-\mathrm{d}-(2,6-\mathrm{di}-\mathrm{O}-\alpha-1-$ rhamnopyranosyl) galactopyronoside (KG) pretreatment showed improvement in the level of thiobarbituric acid reactive substances in the liver, indicating that KG alleviates liver injury [80], which might be due to its antioxidant properties. Kaempferol reduces liver damage in acetaminophen-treated rats by upregulating silent information regulator 1 (SIRT1). It suppresses the acetylation of all SIRT1 targets, including PARP1, p53, NFjB, FOXO-1, and p53 that mediate antioxidant, anti-inflammatory, and anti-apoptotic effects [81]. It also showed a hepatoprotective effect in alcohol-induced liver injury in mice by suppressing the expression of key microsomal enzyme cytochrome 2E1 (Cyp2E1) and by enhancing the protective role of the antioxidative defense system [82]. Various works citing the role of kaempferol in managing severe liver injuries are summarized in Table 2.

Table 2. The role of kaempferol in alleviating liver diseases.

\begin{tabular}{|c|c|c|c|c|}
\hline Diseases Type & $\begin{array}{l}\text { In Vitro/In Vivo } \\
\text { Model }\end{array}$ & Mechanism of Action & Concentrations/Doses & References \\
\hline $\begin{array}{l}\text { Alcoholic liver } \\
\text { injury }\end{array}$ & Mice & $\begin{array}{c}\uparrow \text { expression of butyrate receptors, } \\
\text { transporters, and TJ proteins in the intestinal } \\
\text { mucosa. }\end{array}$ & 25,50 and $100 \mathrm{mg} / \mathrm{kg}$ & [83] \\
\hline $\begin{array}{l}\text { Alcoholic liver } \\
\text { injury }\end{array}$ & ALI mice model & $\begin{array}{l}\text { Increased antioxidant defense activity, } \\
\text { decreased oxidative stress, and lipid } \\
\text { peroxidation. }\end{array}$ & 10 and $20 \mathrm{mg} / \mathrm{kg}$ & [82] \\
\hline Liver injury & $\begin{array}{l}\text { Bosentan-induced rat } \\
\text { liver injury model } \\
\text { and HEK-293 cells }\end{array}$ & $\begin{array}{l}\text { Inhibition of OATP1B1 transporter, } \\
\text { maintaining a level of AST, ALT }\end{array}$ & $\begin{array}{l}25 \mathrm{mg} / \mathrm{kg} \text { and } \\
1-150 \mu \mathrm{M}\end{array}$ & [84] \\
\hline Liver injury & $\begin{array}{l}\text { Male Swiss albino } \\
\text { rats }\end{array}$ & $\begin{array}{l}\text { Inhibition of lipid peroxidation caused by } \\
\text { CCL4 reactive free radicals. }\end{array}$ & $25 \mathrm{mg} / \mathrm{kg}$ & [85] \\
\hline Liver injury & Male ddY mice & $\begin{array}{l}\downarrow \text { TBARS and TNF- } \alpha \text { level in CCL4 } \\
\text { treated mice. }\end{array}$ & $4.9 \mathrm{mg} / \mathrm{kg}$ & [80] \\
\hline Liver injury & Mice and HepG2 cells & $\begin{array}{c}\text { Reduces } \mathrm{AA}+\mathrm{Fe} \text {-induced ROS production } \\
\text { and reversed glutathione depletion, } \\
\downarrow \\
\downarrow \text { cell death. }\end{array}$ & $\begin{array}{l}250 \text { and } 500 \mathrm{mg} / \mathrm{kg} \\
\text { and } 100,200 \text { and } \\
400 \mu \mathrm{M}\end{array}$ & [86] \\
\hline Liver fibrosis & L02, LX2 and Rats & $\begin{array}{c}\downarrow \text { Protein levels of cleaved caspase- } 3, \uparrow \\
\text { p-ERK1/2, PI3K, and Bcl-XL protein } \\
\text { expression in TNF- } \alpha \text {-stimulated L02 cells. } \\
\text { The suppressed proliferation of LX2 cells and } \\
\text { up-regulation of Bax and cleaved caspase- } 8 \text {. }\end{array}$ & $20 \mu \mathrm{M}$ & [87] \\
\hline Liver fibrosis & $\begin{array}{l}\text { HSCs/Ccl4 induced } \\
\text { mouse model }\end{array}$ & $\begin{array}{c}\text { Down-regulation of hyaluronic acid, ALT, } \\
\text { AST, Smad2/3. } \\
\text { Inhibits collagen synthesis and activation of } \\
\text { HSCs cells. } \\
\text { Suppression of activin receptor-like kinase } 5 .\end{array}$ & $2-10 \mu \mathrm{mol} / \mathrm{L}$ & [88] \\
\hline Liver cancer & HepG2 & $\begin{array}{c}\text { Apoptosis, reduced expression of miR-21, } \\
\text { upregulation of PTEN expression and } \\
\text { PI3K/AKT/mTOR signaling pathways } \\
\text { inactivation. }\end{array}$ & $\begin{array}{c}0,25,50,75, \text { and } \\
100 \mu \mathrm{M}\end{array}$ & [20] \\
\hline
\end{tabular}


Table 2. Cont.

\begin{tabular}{|c|c|c|c|c|}
\hline Diseases Type & $\begin{array}{l}\text { In Vitro/In Vivo } \\
\text { Model }\end{array}$ & Mechanism of Action & Concentrations/Doses & References \\
\hline Liver cancer & HepG2 cells & $\begin{array}{c}\uparrow \text { PIG3 level at mRNA and protein level, } \\
\uparrow \text { ROS production, cytochrome C release, } \downarrow \\
\text { mitochondrial membrane potential, } \\
\text { upregulation of Bax } / \text { Bcl-2, activation of } \\
\text { caspases- } 9 \text { and }-3 \text {, and maintaining the } \\
\text { pro-oxidant activity. }\end{array}$ & $10,20,40$ and $80 \mu \mathrm{M}$ & [89] \\
\hline $\begin{array}{l}\text { Human hepatic } \\
\text { cancer }\end{array}$ & SK-HEP-1 & $\begin{array}{c}\uparrow \text { protein levels of p-AMPK, LC3-II, Atg 5, } \\
\text { Atg } 7, \text { Atg } 12 \text { and Beclin } 1, \downarrow \text { level of CDK1, } \\
\text { cyclin B, p-AKT, and p-Mtor. Downregulation } \\
\text { of CDK1/Cyclin B pathways, Induces } \\
\text { autophagy. }\end{array}$ & $\begin{array}{c}0,25,50,75 \text { and } \\
100 \mu \mathrm{M}\end{array}$ & [17] \\
\hline HCC & Huh 7 & $\begin{array}{l}\text { HIF-1a activity inactivation by cytoplasmic } \\
\text { mislocalization and MAPK pathway } \\
\text { inhibition. }\end{array}$ & $1-100 \mu \mathrm{M}$ & [90] \\
\hline HCC & HepG2 & $\begin{array}{l}\text { 个 The hypolipidemic effect through LDL-c } \\
\text { uptake. }\end{array}$ & $15 \mu \mathrm{M}$ & [91] \\
\hline HCC & HepG2 cells & $\begin{array}{l}\uparrow \text { phosphorylation of JAK } 1, \text { Tyk } 2 \text {, and } \\
\text { STAT } 1 / 2, \downarrow \text { phosphorylation of STAT3, } \\
\text { promoted endogenous IFN- } \alpha \text {-regulated genes } \\
\text { expression, } \downarrow \text { expression of SOCS3, } \uparrow \text { the } \\
\text { anti-proliferative effect of IFN- } \alpha \text {, activation of } \\
\text { the JAK/STAT signaling pathway }\end{array}$ & $10 \mu \mathrm{g} / \mathrm{mL}$ & [92] \\
\hline Hepatotoxicity & Male C57BL/6 mice & $\begin{array}{c}\text { Decreased level of ALT, AST. Induce } \\
\text { hepatocellular damage, } \uparrow \text { expression of } \\
\text { antioxidant enzymes, and apoptosis. Reduces } \\
\text { NLRP3 expression and pro-inflammatory } \\
\text { factors. Inhibition of HMGBI/TLR4/NF-KB } \\
\text { signaling pathway. }\end{array}$ & 30 and $60 \mathrm{mg} / \mathrm{kg}$ & [93] \\
\hline $\begin{array}{l}\text { Acrylamide } \\
\text { hepatic } \\
\text { intoxication }\end{array}$ & $\begin{array}{l}\text { Wistar female albino } \\
\text { rats }\end{array}$ & Reduced TBAR and GSH level & $\begin{array}{l}5,10,20 \text { and } \\
40 \mathrm{mg} / \mathrm{kg}\end{array}$ & [94] \\
\hline $\begin{array}{l}\text { Nonalcoholic } \\
\text { steatohepatitis } \\
\text { (NASH) }\end{array}$ & Male C57BL/6 mice & $\begin{array}{c}\downarrow \text { level of ALT, LDL, triglycerides, total } \\
\text { cholesterol, lipid droplets and inflammatory } \\
\text { cells infiltration in the liver, Upregulation of } \\
\text { DEGs, Regulation of fatty acid degradation, } \\
\text { expression of cytochrome P450, } \downarrow \text { level of } \\
\text { urinary proteins family (Mup17, Mup7, and } \\
\text { Mup16). }\end{array}$ & $4 \mathrm{mg} / \mathrm{mL}$ & [95] \\
\hline NAFLD & HepG2 cells & $\begin{array}{c}\downarrow \text { hepatic lipid accumulation, promote } \beta \\
\text { oxidation in mitochondria and up-regulation } \\
\text { of the expression of CPT1A }\end{array}$ & $20 \mu \mathrm{g} / \mathrm{mL}$ & [96] \\
\hline
\end{tabular}

Several signaling pathways and molecular mechanisms have been identified that play prominent roles in reducing oxidative stress. Targeting the critical pathways which include peroxisome proliferator-activated receptor (PPAR) and nuclear factor erythroid related factor 2 (Nrf2) using kaempferol has shown a positive effect in relieving oxidative stress.

\subsection{Peroxisome Proliferator-Activated Receptor (PPAR)}

PPAR belongs to the nuclear receptor superfamily [97]. Among the various PPAR receptors identified, PPAR $\alpha$ and PPAR $\gamma$ play an important role in the regulation of lipids and glucose metabolism [98]. The subtypes of PPAR receptors have been shown to be involved in the pathogenesis of HCC. Due to the increased consumption of nutrients, 
HCC cells experience oxygen and nutrient deficiency leading to a stressful metabolic environment [99]. PPAR $\alpha$ acts as a master regulator of liver metabolism. Therefore, $\operatorname{PPAR} \alpha$-regulated processes are involved in most liver diseases. HCC is associated with the down-regulation of PPAR $\alpha$ receptors [99]. Thus, stimulation of PPAR $\alpha$ is expected to treat HCC. Kaempferol, a polyphenolic compound shows the protective effect by elevating the expression of the PPAR $\alpha$ gene and/or protein [100].

\subsection{Nuclear Factor Erythroid Related Factor 2 (Nrf2)}

Nrf2, a cytosolic transcription factor, is the principal regulator of cellular defense through the antioxidant machinery [101]. In normal liver cells, Nrf2 offers protective effects against oxidative stress, whereas, in the tumor cells it causes deleterious effects, encouraging the proliferation and survival of cancerous cells [102]. Under normal physiological conditions, Nrf2 and Kelch-like ECH-associated protein 1 (KEAP1) orchestrate the NRF2dependent oxidative stress response and maintain liver homeostasis. Upon continuous stress exposure, Keap 1 is degraded in the cytoplasm. Further, Nrf2 is phosphorylated and translocated to the nucleus, forming a heterodimer with transcription factor Maf. It binds to the antioxidant response element (ARE) sequence and activates the expression of endogenous antioxidants, phase II detoxifying enzymes and transporters [103]. Nrf2 can act as the potential target for managing severe cancers including HCC [101]. Thus, kaempferol can regulate the Nrf2 transcriptional pathway and reduce cell redox homeostasis, and can play a promising role in combatting cancer [14]. Figure 2 exhibits the antioxidant role of kaempferol during HCC.



Figure 2. Antioxidant mechanism of KP via Nrf2-Keap1 pathway. KP inhibits the metabolism of ROS by acting on the Nrf2-Keap1 complex. The level of Nrf2 is augmented by KP after its disassociation from the complex. Nrf2 translocates to the nucleus and binds with ARE along with Maf transcription factor, which triggers the expression of the genes, inducing autophagy, inhibiting oxidation and inflammation. KP also plays a vital role in suppressing the mitochondrial membrane potential disruption and thus leading to restoration of normal physiological condition. Abbreviations: KP, kaempferol; Nrf2, nuclear factor erythroid 2 related factors 2; Keap1, Kelch-like ECH-associated protein 1. 


\section{Role of Oxidative Stress in Endoplasmic Reticulum (ER) Hemostasis}

The ER is involved in protein folding, synthesis, and secretion [104,105]. Nutrient distress, $\mathrm{pH}$ imbalance, and, hypoxia perturb ER homeostasis, thus affecting the protein folding machinery and the generation of misfolded proteins [106]. The accumulation of misfolded proteins causes cellular damage and induces ER stress [107]. Prolonged ER stress activates a self-protective mechanism, the unfolded response (UPR). It reduces protein synthesis and enhances the expression of the ER molecular chaperones glucose-regulated protein 78 (GRP78) and GRP94 to facilitate the correct folding of proteins. UPR is the complex cellular response that is associated with the various membrane biosensors; protein kinase RNA (PKR)-like ER kinase (PERK), inositol requiring enzyme $1 \alpha$ (IRE1 $\alpha$ ), and activating transcription factor 6 (ATF6) [97]. Other studies have also indicated that oxidative stress is strongly connected with ER stress $[108,109]$. Both of them trigger various inflammatory molecules and apoptosis cascades which are involved in the pathogenesis of many diseases, specifically liver injuries. In the ER lumen, stable protein folding requires the formation of disulfide bonds between cysteine residues of the proteins [110]. Glutathione (GSH), a non-protein thiol present abundantly in eukaryotic cells, can be reduced to glutathione disulfide (GSSG), which is important in maintaining ER redox hemostasis and which ensures correct protein folding [111]. An imbalance between the glutathione (GSH/GSSH) ratio and the generation of misfolded proteins leads to the production of ROS [112]. In eukaryotes, protein folding is regulated by multifunctional chaperons and oxidoreductases (protein disulfide isomerase (PDI)). PDI accepts a pair of electrons from the cysteine residues in polypeptide substrates, resulting in its reduction and the oxidation of its substrates. Further, PDI transfers the electrons to the ER oxidoreductase 1 (ERO1), which further transfers it to the molecular oxygen and produces $\mathrm{H}_{2} \mathrm{O}_{2}$ to start a new cycle (Figure 3) [113].



Figure 3. Protein folding in ER in the presence of oxidative stress. In eukaryotic cells, protein folding in ER is regulated by different proteins (PDI and ERO1). Impaired disulfide bond formation leads to the accumulation of misfolded proteins resulting in oxidative stress. Abbreviations: ER, endoplasmic reticulum; ERO1, ER oxidoreductin 1; FFA, free fatty acids; GSH, glutathione; GSSG, glutathione disulfide; NADPH, nicotinamide adenine dinucleotide phosphate; PDI, protein disulfide isomerase. 
Oxidative stress activates ER stress cascade and alleviates the expression of ER transmembrane proteins, e.g., ATF6, CHOP, and ATF4. A decrease in oxidative stress means a decrease in ER stress [114]. The correlation of oxidative stress with ER stress in liver injuries has been reported by a number of authors. Kim et al. (2018) showed that TM-induced ER stress increases MDA levels, GRP 78, and CHOP, and decreases GSH levels in liver cancer cell lines [97]. Moslehi et al. (2019) showed that TM-induced ER stress attenuates amygdalin. It can be said that amygdalin works through antioxidant machinery to combat ER stress [115]. Zhang et al. (2019) reported the pathogenic role of oxidative stress and ER stress in the early initiating stages of non-alcoholic fatty liver diseases (NAFLD) [116].

\section{Endoplasmic Reticulum Stress Signaling Pathways}

The ER stress pathway has been considered the most efficient apoptosis signaling pathway and has a vital role in human liver cancer. IRE1 $\alpha$-XBP1, PERK-eIF2 $\alpha$-ATF4, ATF6 are the UPR signaling pathways that promote cell death in response to ER stress (Figure 4). The functions of each UPR mediator and their possible links to apoptotic signaling are discussed below.

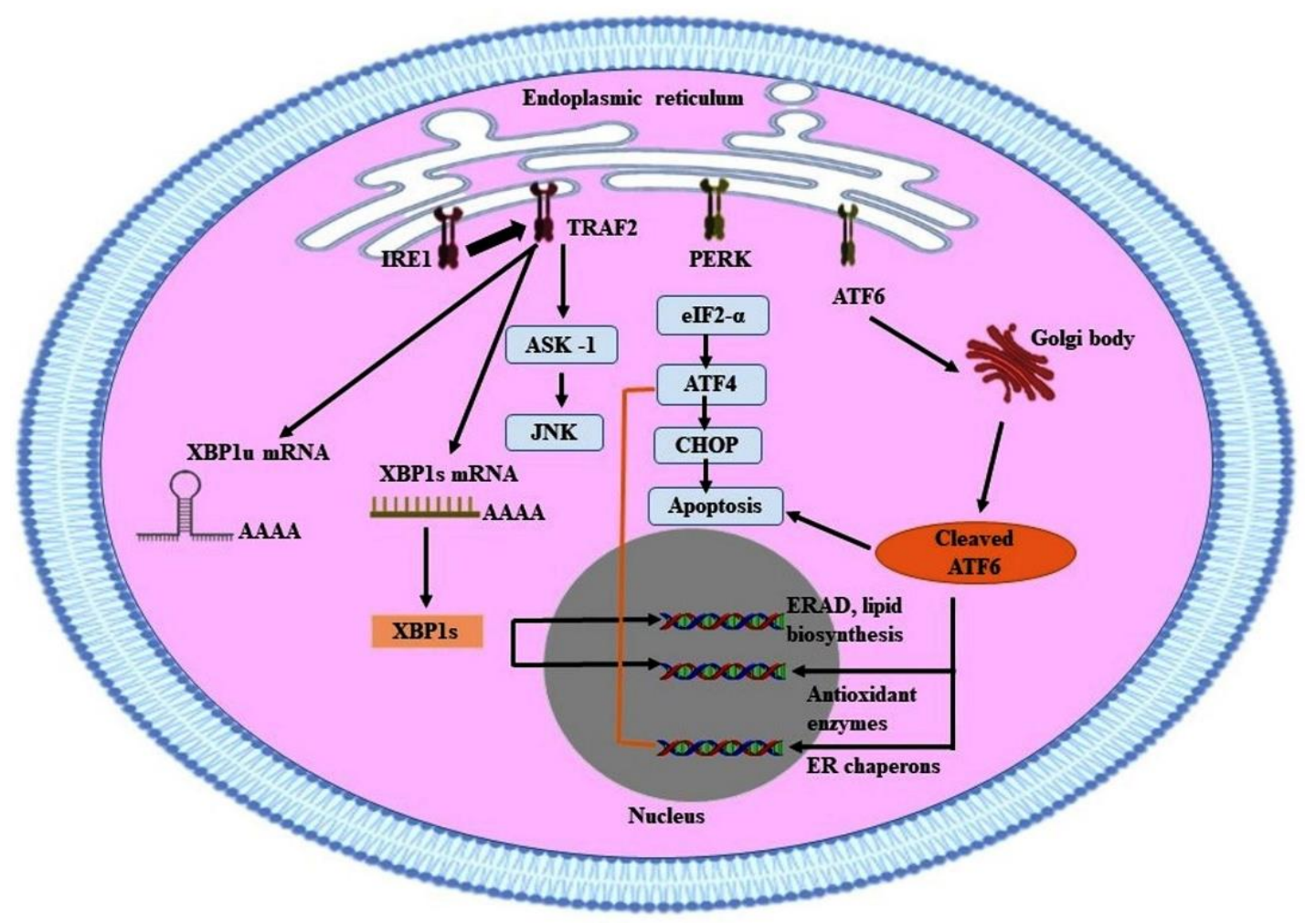

Figure 4. Adaptive pathways of ER stress. ER stress is induced due to the accumulation of misfolded and poorly folded proteins in the ER lumen. ER stress triggers UPR, which attenuates protein translation, enhances protein folding capacity, and thus re-establishes ER hemostasis. ER-resident chaperons interact with each other. Grp78/BiP interacts with three ER transmembrane proteins, viz. IRE- $1 \alpha$, PERK and ATF6. IRE- $1 \alpha$ regulates the splicing of XBP1, which regulates the upregulation of ERAD. PERK phosphorylates eIF2 $\alpha$, which further activates ATF4 and thus increases the ER's protein folding capacity. ATF6 gets cleaved by the specific proteases residing in the Golgi bodies, thus enhancing the expression of UPR genes and ERAD. Abbreviations: UPR, unfolded protein response; Grp78, glucose-regulated protein 78; BiP, binding protein; IRE- $1 \alpha$, Inositol requiring enzyme $1 \alpha$; PERK, protein kinase RNA-like ER kinase; ATF6, activation transcription factor; XBP1, X- box-binding protein; ERAD, ER-associated degradation; eIF2 $\alpha$, eukaryotic transcription factor 2; ATF4, Activation transcription factor. 


\subsection{IRE1 $\alpha$-XBP1 Pathway}

IRE1 is the transmembrane type-I protein that possesses both kinase and endoribonuclease (RNAse) activities and helps in modulating ER stress [117]. IRE1 exists in two isoforms, IRE1 $\alpha$ and IRE1 $\beta$. The IRE1 $\alpha$ is expressed extensively, whereas IRE1 $\beta$ expression is confined to the intestinal epithelium and gastrointestinal tract. IRE1 $\alpha$-knockout mice exhibit embryonic lethality, while IRE1 $\beta$ knockout in mice is viable. Thus, IRE1 $\alpha$ is considered a positive regulator for mammalian cell survival [118]. During ER stress, IRE1 $\alpha$ disassociates from GRP78/Bip [119], undergoes dimerization, and autophosphorylation. $\mathrm{X}$-box binding protein 1 (XBP-1) mRNA is the first substrate described for IRE1 $\alpha$ endonuclease activity [120], which stimulates the non-conventional splicing of XBP-1 mRNA to produce its active form that is spliced XBP-1 [121]. This activated form of XBP1 encourages the expression of ER quality-control genes, thus enhancing the protein folding capacity of the ER. Spliced XBP1 modulates the expression of genes involved in protein folding, secretion, redox homeostasis, oxidative stress response, and ER-associated degradation (ERAD) [122]. IRE1 $\alpha$-XBP1 signaling has been reported to possess a prominent role in human cancer including HCC [123].

\subsection{PERK-eIF2 $\alpha$-ATF4 Pathway}

The enzyme protein kinase R-like endoplasmic reticulum kinase (PERK) is an ER transmembrane protein that is associated with BiP/GRP78 in its inactive form. On UPR activation, it becomes dissociated from the Bip/GRP78 complex and undergoes oligomerization and autophosphorylation, and thus becomes activated [124]. Active PERK plays an important role in suppressing global protein synthesis by attenuating mRNA translation and inhibiting the entry of new proteins into the ER lumen. This process is regulated by phosphorylation-mediated inactivation of the eukaryotic translation initiation factor 2 (eIF $2 \alpha$ ). Phosphorylation of eIF $2 \alpha$ at Ser51 residue inhibits protein translation by reducing the Cyclin D1 pool and cell cycle arrest at the G1 phase, which ultimately diminishes protein burden and helps the cells to overcome the stressful conditions [125]. The activated PERK- eIF2 $\alpha$ promotes the translation of ATF4, which encourages cell survival by regulating protein biosynthesis and transport. Cells lacking PERK are reported to be supersensitive to ER stress conditions. Thus, inhibition of the PERK- eIF2 $\alpha$-ATF4 signaling pathway could be a promising target for cancer prevention.

\subsection{ATF6 Pathway}

ATF6 is a type II transmembrane protein from the leucine zipper family of transcription factors [126]. It is the cytoprotective factor and ER stress modulator that participates actively in the UPR signaling pathway [127]. Under chronic ER stress, an isoform ATF6 $\alpha$ disassociates from the GRP78 proteins and translocates to the Golgi apparatus, where it undergoes proteolysis by the resident Site $1(\mathrm{~S} 1 \mathrm{P})$ and Site $2(\mathrm{~S} 2 \mathrm{P})$ proteases. This releases a cytosolic fragment that migrates to the nucleus and regulates transcription [125]. To maintain ER hemostasis, cleaved ATF6 $\alpha$ plays a prominent role in the regulation of genes involved in protein synthesis and ER-associated degradation (ERAD) [128].

\section{Role of Kaempferol in ER Stress and Oxidative Stress-Induced Apoptosis}

Uncontrolled and sustained ER stress leads to cellular damage and eventually induces apoptosis by activating the mitochondrial intrinsic apoptotic pathway. This pathway is activated by various micro-environmental stimuli, such as DNA damage, ER stress, ROS overload, and replication stress [129]. During prolonged ER stress, PERK induces selective translation of ATF4 and transcription of the CHOP gene, which ultimately results in the activation of apoptotic machinery [130]. Several studies have shown the importance of kaempferol in ER stress and oxidative stress-induced apoptosis through a different mechanism (Table 3). Kaempferol induces apoptosis in the liver cancer cell line via the ER stress-CHOP signaling pathway by increasing the protein expression levels of Grp78, Grp94, PERK, IRE1 $\alpha$, ATF6, caspase 4, CHOP, and cleaved caspase 3 [131]. Kaempferol 
pretreatment impedes hepatocyte apoptosis to protect mice from liver failure by regulating the ER stress-Grp78-CHOP signaling pathway [132]. Kaempferol has shown a protective effect in rat hepatoma cells over a broad concentration range by inducing oxidative stress and apoptosis [133]. Additionally, some researchers have revealed the antioxidant ability of kaempferol (present in aqueous Pepino leaf extract (AEPL)) on HepG2 cells by promoting the expression of Nrf2 and its target genes (SOD1 and GPX3), reducing ER stress and inhibiting apoptosis [134].

Table 3. Role of kaempferol in the induction of cell death (apoptosis/autophagy) through ER stress and oxidative stress pathways [48-141].

\begin{tabular}{|c|c|c|c|c|}
\hline Diseases Type & In Vitro/In Vivo Model & Mechanism of Action & Concentations/Doses & References \\
\hline Acute liver failure & $\begin{array}{c}\text { Murine ALF model induced } \\
\text { by D-galactosamine/ } \\
\text { lipopolysaccharide mice }\end{array}$ & $\begin{array}{c}\text { Regulation of ER } \\
\text { stress-Grp78-CHOP pathway }\end{array}$ & $5 \mathrm{mg} / \mathrm{kg}$ & [132] \\
\hline HCC & HepG2 & $\begin{array}{l}\text { Apoptosis, and Upregulation of } \\
\text { CHOP gene expression. }\end{array}$ & $\begin{array}{c}0,5,10,2550 \text { and } \\
100 \mu \mathrm{M}\end{array}$ & [131] \\
\hline HCC & H4IIE & $\begin{array}{c}\mathrm{H}_{2} \mathrm{O}_{2} \text { mediated lipid peroxidation } \\
\text { leading to cell death and DNA } \\
\text { damage, } \uparrow \text { the activity of } \\
\text { caspases- }-2,-3 / 7,-9 \text {, and }-8 / 10 \text {, and } \\
\text { apoptosis. }\end{array}$ & $5-25 \mu \mathrm{M}$ & [133] \\
\hline HCC & HepG2 and Huh 7 & $\begin{array}{l}\uparrow \text { The protein level of Atg5, Atg7, } \\
\text { Beclin1, and Overexpression of } \\
\text { CHOP induces autophagy. }\end{array}$ & $5 \sim 100 \mu \mathrm{M}$ & [48] \\
\hline NASH & $\begin{array}{l}\text { HepG2 cells/C57BL/6 } \\
\text { NASH mice model }\end{array}$ & $\begin{array}{l}\text { Decresed expression of LXR } \alpha \text {, } \\
\text { LPCAT3 and ERS-related factors } \\
\text { PERK, eIF2 } \alpha, \text { ATF6, ATF4, XBP1, } \\
\text { CHOP, IRE1 } \alpha \text { and GRP78 and } \\
\text { induction of apoptosis. }\end{array}$ & $\begin{array}{l}20,40,60 \mu \mathrm{mol} / \mathrm{L} \\
\text { and } 20 \mathrm{mg} / \mathrm{kg}\end{array}$ & [141] \\
\hline $\begin{array}{l}\text { Hepatocellular } \\
\text { lipotoxicity }\end{array}$ & HepG2 & $\begin{array}{c}\text { Decreased ER stress, increased } \\
\text { antioxidant ability and inhibited } \\
\text { apoptosis. }\end{array}$ & $1,5,10,100 \mu \mathrm{g} / \mathrm{mL}$ & [134] \\
\hline
\end{tabular}

\section{Modulation of ER Stress and Autophagy Machinery by Kaempferol}

Oxidative stress and ER stress tend to function through autophagy, which is a selfdegradative process and plays an essential role in removing misfolded and degradative proteins and clearing damaged cellular organelles [135]. Interestingly, some researchers have found that autophagy itself is capable of preventing cancer in some phases via tissue damage and genomic instability, etc [136].

The ER, being a trafficking organelle, drives the cell towards death. The autophagy machinery is activated in response to ER stress [137]. Disruption in the autophagic process and alteration in ER hemostasis may promote serious liver diseases. Therefore, identifying and targeting the pathways with the help of traditional drugs appears to be beneficial in its treatment. Kaempferol exerts a positive effect on the autophagic machinery in combatting cancer [118]. Many researchers have demonstrated the modulatory effect of kaempferol on autophagy in different human cancers. In gastric cancer cells, kaempferol induces autophagic cell death via activating the IRE1-JNK-CHOP signaling pathway and inhibiting G9a cells [97]. Furthermore, another study validates the inhibitory effect of kaempferol in autophagy in lung cancer cells. Cells treated with kaempferol showed miR340 overexpression, elevated PTEN, and reduced p-PI3K and p-AKT levels. The autophagic induction was confirmed through the increased expression of LC3-II, ATG7 and Beclin 1, and the reduced expression of p62 [18]. Kaempferol is found to inhibit cell proliferation, motility, and invasion by stimulating apoptosis and autophagy in RKO, HCT-116, HT-29, 
and DLD-1 colon cancer cell lines [138]. Kaempferol possesses anti-glioma activity by generating ROS and subsequently autophagy followed by pyroptosis (an inflammatory form of programmed cell death activated by some inflammasomes) in glioblastoma cell lines [83].

Kaempferol helps in modulating ER stress and autophagy, thus protecting the cells against malfunction [139]. Few reports are available indicating the potential of kaempferol in preventing HCC via autophagy and ER stress (Table 3). It induces cell mortality derived from autophagy by triggering the AMPK signaling pathway [140]. Kaempferol showed a concentration- and time-dependent inhibitory effect on liver cancer cells by inducing autophagy via the ER stress-CHOP signaling pathway [48].

\section{Conclusions and Future Perspective}

Kaempferol has been introduced into medical research due to its cancer-preventive activity. It specifically inhibits cancerous cells without disturbing the normal ones. It exerts chemopreventive effects against HCC by inducing mitochondrial apoptosis, autophagy, cell cycle arrest, ER stress, etc. The latest research on kaempferol shows it as an immune checkpoint modulator. Moreover, it can be used in combination with sorafenib and doxorubicin to enhance its efficacy in treating HCC and liver cancer.

Most of the research on the anti-cancer potential of kaempferol was carried out using human cell lines (in vitro). There are inadequate data on animal (in vivo) studies and clinical trials. There is an immense need for more in-depth in vivo experiments which will establish kaempferol as a more suitable and potent candidate as a chemopreventive agent against HCC.

Additionally, oxidative stress and ER stress both play a prominent role in different liver diseases, including HCC. Various reports show a close connection between oxidative stress and ER stress, but the molecular mechanism behind this association in hepatocarcinogenesis has not yet been completely explored. Therefore, further studies are required to determine the molecular mechanism of the interaction between OS and ER stress signaling in liver diseases.

Moreover, there are limitations in using kaempferol for the treatment of cancer, because of its poor solubility and bioavailability. This can be enhanced if it is given in combination with other anti-cancer drugs. Nanoformulations of kaempferol can also be prepared to increase its bioavailability.

Funding: This research received no external funding.

Acknowledgments: The authors are thankful to Meenakshi Gupta (Research Scholar, Amity Institute of Pharmacy, Amity University, Noida, and Uttar Pradesh, India) for her insightful comments.

Conflicts of Interest: The authors declare no conflict of interest.

\section{References}

1. Moratalla-López, N.; Lorenzo, C.; Alonso, G.L.; Sánchez, A.M. Kaempferol glycosides in Crocus: Sources, biosynthesis, and uses. In Kaempferol: Biosynthesis, Food Sources and Therapeutic Uses, 2016th ed.; Nova Science Publisher: Hauppauge, NY, USA, 2016; pp. 151-195.

2. Dabeek, W.M.; Marra, M.V. Dietary quercetin and kaempferol: Bioavailability and potential cardiovascular-related bioactivity in humans. Nutrients 2019, 11, 2288. [CrossRef]

3. Sumaiya, S.; Sharma, A.; Naved, T.; Sarwat, M. Amelioration of liver ailments by saffron (Crocus sativus) and its secondary metabolites. In Saffron: The Age Old Panacea in New Light; Sarwat, M., Sumaiya, S., Eds.; Elsevier: Amsterdam, The Netherlands, 2020; pp. 1-20.

4. Alam, W.; Khan, H.; Shah, M.A.; Cauli, O.; Saso, L. Kaempferol as a dietary anti-inflammatory agent: Current therapeutic standing. Molecules 2020, 25, 4073. [CrossRef]

5. Afrin, S.; Haneefa, S.M.; Fernandez-Cabezudo, M.J.; Giampieri, F.; Al-Ramadi, B.K.; Battino, M. Therapeutic and preventive properties of honey and its bioactive compounds in cancer: An evidence-based review. Nutr. Res. Rev. 2020, 33, 50-76. [CrossRef] [PubMed] 
6. Li, H.; Ji, H.S.; Kang, J.H.; Shin, D.H.; Park, H.Y.; Choi, M.S.; Lee, C.H.; Lee, I.K.; Yun, B.S.; Jeong, T.S. Soy leaf extract containing kaempferol glycosides and pheophorbides improves glucose homeostasis by enhancing pancreatic $\beta$-cell function and suppressing hepatic lipid accumulation in db/db mice. J. Agric. Food Chem. 2015, 63, 7198-7210. [CrossRef] [PubMed]

7. Zhou, M.; Ren, H.; Han, J.; Wang, W.; Zheng, Q.; Wang, D. Protective effects of kaempferol against myocardial ischemia/reperfusion injury in isolated rat heart via antioxidant activity and inhibition of glycogen synthase kinase-3. Oxidative Med. Cell. Longev. 2015, 2015, 481405. [CrossRef]

8. Ma, Y.; Liu, Y.; Sun, A.; Du, Y.; Ye, M.; Pu, X.; Qi, X. Intestinal absorption and neuroprotective effects of kaempferol-3-O-rutinoside. RSC Adv. 2017, 7, 31408-31416. [CrossRef]

9. Chandramohan, G.; Al-Numair, K.S.; Alsaif, M.A.; Veeramani, C. Antidiabetic effect of kaempferol a flavonoid compound, on streptozotocin-induced diabetic rats with special reference to glycoprotein components. Prog. Nutr. 2015, 17, 50-57.

10. Vellosa, J.C.; Regasini, L.O.; Khalil, N.M.; Bolzani, V.D.; Khalil, O.A.; Manente, F.A.; Netto, H.P.; Oliveira, O.M. Antioxidant and cytotoxic studies for kaempferol, quercetin and isoquercitrin. Eclética Quim. 2011, 36, 7-20. [CrossRef]

11. Tatsimo, S.J.; de Dieu Tamokou, J.; Havyarimana, L.; Csupor, D.; Forgo, P.; Hohmann, J.; Kuiate, J.R.; Tane, P. Antimicrobial and antioxidant activity of kaempferol rhamnoside derivatives from Bryophyllum pinnatum. BMC Res. Notes 2012, 5, 158. [CrossRef] [PubMed]

12. Kim, S.H.; Choi, K.C. Anti-cancer effect and underlying mechanism (s) of kaempferol, a phytoestrogen, on the regulation of apoptosis in diverse cancer cell models. Toxicol. Res. 2013, 29, 229-234. [CrossRef]

13. Patel, S.; Sarwat, M.; Khan, T.H. Mechanism behind the anti-tumour potential of saffron (Crocus sativus L.): The molecular perspective. Crit. Rev. Oncol./Hematol. 2017, 115, 27-35. [CrossRef] [PubMed]

14. Imran, M.; Salehi, B.; Sharifi-Rad, J.; Gondal, T.A.; Saeed, F.; Imran, A.; Shahbaz, M.; Fokou, P.V.T.; Arshad, M.U.; Khan, H.; et al. Kaempferol: A key emphasis to its anticancer potential. Molecules 2019, 24, 2277. [CrossRef]

15. Crespy, V. The splanchnic metabolism of flavonoids highly differed according to the nature of the compound. Am. J. Physiol. Gastrointest. Liver Physiol. 2003, 284, G980-G988. [CrossRef]

16. Ren, J.; Lu, Y.; Qian, Y.; Chen, B.; Wu, T.; Ji, G. Recent progress regarding kaempferol for the treatment of various diseases. Exp. Ther. Med. 2019, 18, 2759-2776. [CrossRef] [PubMed]

17. Huang, W.W.; Tsai, S.C.; Peng, S.F.; Lin, M.W.; Chiang, J.H.; Chiu, Y.J.; Fushiya, S.; Tseng, M.T.; Yang, J.S. Kaempferol induces autophagy through AMPK and AKT signaling molecules and causes G2/M arrest via downregulation of CDK1/cyclin B in SK-HEP-1 human hepatic cancer cells. Int. J. Oncol. 2013, 42, 2069-2077. [CrossRef] [PubMed]

18. Han, X.; Liu, C.F.; Gao, N.; Zhao, J.; Xu, J. Kaempferol suppresses proliferation but increases apoptosis and autophagy by up-regulating microRNA-340 in human lung cancer cells. Biomed. Pharmacother. 2018, 108, 809-816. [CrossRef] [PubMed]

19. Li, Q.; Wei, L.; Lin, S.; Chen, Y.; Lin, J.; Peng, J. Synergistic effect of kaempferol and 5-fluorouracil on the growth of colorectal cancer cells by regulating the PI3K/Akt signaling pathway. Mol. Med. Rep. 2019, 20, 728-734. [CrossRef]

20. Zhu, G.; Liu, X.; Li, H.; Yan, Y.; Hong, X.; Lin, Z. Kaempferol inhibits proliferation, migration, and invasion of liver cancer HepG2 cells by down-regulation of microRNA-21. Int. J. Immunopathol. Pharmacol. 2018, 32. [CrossRef]

21. Zamora-Ros, R.; Fedirko, V.; Trichopoulou, A.; González, C.A.; Bamia, C.; Trepo, E.; Nöthlings, U.; Duarte-Salles, T.; Serafini, M.; Bredsdorff, L.; et al. Dietary flavonoid, lignan and antioxidant capacity and risk of hepatocellular carcinoma in the European prospective investigation into cancer and nutrition study. Int. J. Cancer 2013, 133, 2429-2443. [CrossRef] [PubMed]

22. Woo, H.D.; Kim, J. Dietary flavonoid intake and smoking-related cancer risk: A meta-analysis. PLoS ONE 2013, 8, e75604. [CrossRef]

23. Nair, B.; Anto, R.J.; Sabitha, M.; Nath, L.R. Kaempferol-mediated sensitization enhances chemotherapeutic efficacy of sorafenib against hepatocellular carcinoma: An in silico and in vitro approach. Adv. Pharm. Bull. 2020, 10, 472-476. [CrossRef]

24. Kampkötter, A.; Nkwonkam, C.G.; Zurawski, R.F.; Timpel, C.; Chovolou, Y.; Wätjen, W.; Kahl, R. Effects of the flavonoids kaempferol and fisetin on thermotolerance, oxidative stress and FoxO transcription factor DAF-16 in the model organism Caenorhabditis elegans. Arch. Toxicol. 2007, 81, 849-858. [CrossRef] [PubMed]

25. Liao, W.; Chen, L.; Ma, X.; Jiao, R.; Li, X.; Wang, Y. Protective effects of kaempferol against reactive oxygen species-induced hemolysis and its antiproliferative activity on human cancer cells. Eur. J. Med. Chem. 2016, 114, 24-32. [CrossRef] [PubMed]

26. Halliwell, B. Antioxidant defence mechanisms: From the beginning to the end (of the beginning). Free Radic. Res. 1999, 31, 261-272. [CrossRef]

27. Ciccarone, F.; Castelli, S.; Ciriolo, M.R. Oxidative stress-driven autophagy acROSs onset and therapeutic outcome in hepatocellular carcinoma. Oxidative Med. Cell. Longev. 2019, 2019, 6050123. [CrossRef]

28. Redza-Dutordoir, M.; Averill-Bates, D.A. Activation of apoptosis signalling pathways by reactive oxygen species. Biochim. Biophys. Acta-Mol. Cell Res. 2016, 1863, 2977-2992. [CrossRef]

29. Shah, A.M.; Channon, K.M. Free radicals and redox signalling in cardiovascular disease. Heart 2004, 90, 486-487. [CrossRef]

30. Misra, M.K.; Sarwat, M.; Bhakuni, P.; Tuteja, R.; Tuteja, N. Oxidative stress and ischemic myocardial syndromes. Med. Sci. Monit. 2009, 15, 209-219.

31. Uttara, B.; Singh, A.V.; Zamboni, P.; Mahajan, R.T. Oxidative stress and neurodegenerative diseases: A review of upstream and downstream antioxidant therapeutic options. Curr. Neuropharmacol. 2009, 7, 65-74. [CrossRef] [PubMed]

32. Namgyal, D.; Ali, S.; Mehta, R.; Sarwat, M. The Neuroprotective effect of curcumin against Cd-induced neurotoxicity and hippocampal neurogenesis promotion through CREB-BDNF signaling pathway. Toxicology 2020, 442, 1-13. [CrossRef] 
33. Bowler, R.P.; Crapo, J.D. Oxidative stress in allergic respiratory diseases. J. Allergy Clin. Immunol. 2002, 110, 349-356. [CrossRef]

34. Klaunig, J.E.; Kamendulis, L.M. The role of oxidative stress in carcinogenesis. Annu. Rev. Pharmacol. Toxicol. 2004, 44, $239-267$. [CrossRef]

35. Rawla, P.; Sunkara, T.; Muralidharan, P.; Raj, J.P. Update in global trends and aetiology of hepatocellular carcinoma. Contemp. Oncol. 2018, 22, 141-150. [CrossRef]

36. Gupta, M.; Chandan, K.; Sarwat, M. Role of miRNA and long non-coding RNA in hepatocellular carcinoma. Curr. Pharm. Des. 2020, 26, 415-428. [CrossRef] [PubMed]

37. Suresh, D.; Srinivas, A.N.; Kumar, D.P. Etiology of Hepatocellular Carcinoma: Special Focus on Fatty Liver Disease. Front. Oncol. 2020, 10, 601710. [CrossRef]

38. Chandan, K.; Gupta, M.; Sarwat, M. Role of host and pathogen-derived micrornas in immune regulation during infectious and inflammatory diseases. Front. Immunol. 2020, 10, 3081-3095. [CrossRef]

39. Raza, A.; Sood, G.K. Hepatocellular carcinoma review: Current treatment, and evidence-based medicine. World J. Gastroenterol. 2014, 20, 4115-4127. [CrossRef] [PubMed]

40. Pasini, F.; Serenari, M.; Cucchetti, A.; Ercolani, G. Treatment options for recurrence of hepatocellular carcinoma after surgical resection: Review of the literature and current recommendations for management. Hepatoma Res. 2020, 6, 26. [CrossRef]

41. Zheng, S.; Xie, Q.; Cheng, J. Salvage liver transplant for hepatocellular carcinoma: Rescues and benefits. Transl. Gastroenterol. Hepatol. 2018, 3, 65. [CrossRef]

42. Paul, S.B.; Manjunatha, Y.C.; Acharya, S.K. Palliative treatment in advanced hepatocellular carcinoma: Has it made any difference? Trop. Gastroenterol. 2010, 30, 125-134.

43. Gupta, M.; Akhtar, J.; Sarwat, M. MicroRNAs: Regulators of immunological reactions in hepatocellular carcinoma. Semin. Cell Dev. Biol. 2021. [CrossRef]

44. Sasaki, Y. Does oxidative stress participate in the development of hepatocellular carcinoma? J. Gastroenterol. 2006, 41, 1135-1148. [CrossRef]

45. Napoletano, F.; Baron, O.; Vandenabeele, P.; Mollereau, B.; Fanto, M. Intersections between regulated cell death and autophagy. Trends Cell Biol. 2019, 29, 323-338. [CrossRef] [PubMed]

46. Pang, L.; Liu, K. Tumor-suppressing effects of autophagy on hepatocellular carcinoma. Liver Res. 2018, 2, 157-160. [CrossRef]

47. Yang, S.; Yang, L.; Li, X.; Li, B.; Li, Y.; Zhang, X.; Ma, Y.; Peng, X.; Jin, H.; Li, H. New insights into autophagy in hepatocellular carcinoma: Mechanisms and therapeutic strategies. Am. J. Cancer Res. 2019, 9, 1329-1353. [PubMed]

48. Guo, H.; Lin, W.; Zhang, X.; Zhang, X.; Hu, Z.; Li, L.; Duan, Z.; Zhang, J.; Ren, F. Kaempferol induces hepatocellular carcinoma cell death via endoplasmic reticulum stress-CHOP-autophagy signaling pathway. Oncotarget 2017, 8, 82207-82216. [CrossRef] [PubMed]

49. Yazdani, H.O.; Huang, H.; Tsung, A. Autophagy: Dual response in the development of hepatocellular carcinoma. Cells 2019, 8, 91. [CrossRef] [PubMed]

50. Marquardt, J.U.; Edlich, F. Predisposition to apoptosis in hepatocellular carcinoma: From mechanistic insights to therapeutic strategies. Front. Oncol. 2019, 13, 1421-1430. [CrossRef]

51. Neuhouser, M.L. Dietary flavonoids and cancer risk: Evidence from human population studies. Nutr. Cancer 2004, 50. [CrossRef] [PubMed]

52. Takaki, A.; Yamamoto, K. Control of oxidative stress in hepatocellular carcinoma: Helpful or harmful? World J. Hepatol. 2015, 7, 968-979. [CrossRef]

53. Gentric, G.; Maillet, V.; Paradis, V.; Couton, D.; L’hermitte, A.; Panasyuk, G.; Fromenty, B.; Celton-Morizur, S.; Desdouets, C. Oxidative stress promotes pathologic polyploidization in nonalcoholic fatty liver disease. J. Clin. Investig. 2015, 125, 981-992. [CrossRef]

54. Tarocchi, M.; Galli, A. Oxidative stress as a mechanism for hepatocellular carcinoma. In Liver Pathophysiology; Elsevier B.V: Amsterdam, The Netherlands, 2017; pp. 279-287.

55. Marra, M.; Sordelli, I.M.; Lombardi, A.; Lamberti, M.; Tarantino, L.; Giudice, A.; Stiuso, P.; Abbruzzese, A.; Sperlongano, R.; Accardo, M.; et al. Molecular targets and oxidative stress biomarkers in hepatocellular carcinoma: An overview. J. Transl. Med. 2011, 9, 171-185. [CrossRef]

56. Wang, Z.; Li, Z.; Ye, Y.; Xie, L.; Li, W. Oxidative stress and liver cancer: Etiology and therapeutic targets. Oxidative Med. Cell. Longev. 2016, 2016, 1-11. [CrossRef]

57. Ha, H.L.; Yu, D.Y. HBx-induced reactive oxygen species activates hepatocellular carcinogenesis via dysregulation of PTEN/Akt pathway. World J. Gastroenterol. 2010, 16, 4932-4937. [CrossRef]

58. El-Serag, H.B. Epidemiology of viral hepatitis and hepatocellular carcinoma. Gastroenterology 2012, 142, 1264-1273. [CrossRef] [PubMed]

59. Hanahan, D.; Weinberg, R.A. Hallmarks of cancer: The next generation. Cell 2011, 144, 646-674. [CrossRef] [PubMed]

60. Li, Y.; Li, S.; Duan, X.; Yang, C.; Xu, M.; Chen, L. Macrophage Phenotypes and Hepatitis B Virus Infection. J. Clin. Transl. Hepatol. 2020, 8, 424-431. [CrossRef] [PubMed]

61. Xu, C.; Zhou, W.; Wang, Y.; Qiao, L. Hepatitis B virus-induced hepatocellular carcinoma. Cancer Lett. 2014, 345, $216-222$. [CrossRef] [PubMed] 
62. Sung, W.K.; Zheng, H.; Li, S.; Chen, R.; Liu, X.; Li, Y.; Lee, N.P.; Lee, W.H.; Ariyaratne, P.N.; Tennakoon, C.; et al. Genome-wide survey of recurrent HBV integration in hepatocellular carcinoma. Nat. Genet. 2012, 44, 765-769. [CrossRef]

63. Jung, S.Y.; Kim, Y.J. C-terminal region of HBx is crucial for mitochondrial DNA damage. Cancer Lett. 2013, 331, 76-83. [CrossRef]

64. Shen, S.; Niso-Santano, M.; Adjemian, S.; Takehara, T.; Malik, S.A.; Minoux, H.; Souquere, S.; Mariño, G.; Lachkar, S.; Senovilla, L.; et al. Cytoplasmic STAT3 represses autophagy by inhibiting PKR activity. Mol. Cell 2012, 48, 667-680. [CrossRef]

65. Formanowicz, D.; Radom, M.; Rybarczyk, A.; Formanowicz, P. The role of Fenton reaction in Ros-induced toxicity underlying atherosclerosis-modeled and analyzed using a Petri net-based approach. Biosystems 2018, 165, 71-87. [CrossRef] [PubMed]

66. Negro, F. Natural history of NASH and HCC. Liver Int. 2020, 40, 72-76. [CrossRef]

67. Day, C.P.; James, O.F. Steatohepatitis: A tale of two "hits"? Gastroenterology 1998, 114, 842-845. [CrossRef]

68. Romeo, S.; Kozlitina, J.; Xing, C.; Pertsemlidis, A.; Cox, D.; Pennacchio, L.A.; Boerwinkle, E.; Cohen, J.C.; Hobbs, H.H. Genetic variation in PNPLA3 confers susceptibility to nonalcoholic fatty liver disease. Nat. Genet. 2008, 40, 1461-1465. [CrossRef]

69. Uchida, D.; Takaki, A.; Oyama, A.; Adachi, T.; Wada, N.; Onishi, H.; Okada, H. Oxidative Stress Management in Chronic Liver Diseases and Hepatocellular Carcinoma. Nutrients 2020, 12, 1576. [CrossRef] [PubMed]

70. Booth, A.; Magnuson, A.; Fouts, J.; Foster, M. Adipose tissue, obesity and adipokines: Role in cancer promotion. Horm. Mol. Biol. Clin. Investig. 2015, 21, 57-74. [CrossRef] [PubMed]

71. Byeon, J.S.; Jeong, J.Y.; Kim, M.J.; Lee, S.M.; Nam, W.H.; Myung, S.J.; Kim, J.G.; Yang, S.K.; Kim, J.H.; Suh, D.J. Adiponectin and adiponectin receptor in relation to colorectal cancer progression. Int. J. Cancer 2010, 127, 2758-2767. [CrossRef] [PubMed]

72. Wu, J.; Du, J.; Liu, L.; Li, Q.; Rong, W.; Wang, L.; Wang, Y.; Zang, M.; Wu, Z.; Zhang, Y.; et al. Elevated pretherapy serum IL17 in primary hepatocellular carcinoma patients correlate to increased risk of early recurrence after curative hepatectomy. PLoS ONE 2012, 7, e50035. [CrossRef]

73. Begriche, K.; Massart, J.; Robin, M.A.; Bonnet, F.; Fromenty, B. Mitochondrial adaptations and dysfunctions in nonalcoholic fatty liver disease. Hepatology 2013, 58, 1497-1507. [CrossRef]

74. Masarone, M.; Rosato, V.; Dallio, M.; Gravina, A.G.; Aglitti, A.; Loguercio, C.; Federico, A.; Persico, M. Role of oxidative stress in pathophysiology of nonalcoholic fatty liver disease. Oxidative Med. Cell. Longev. 2018, 2018, 9547613. [CrossRef] [PubMed]

75. Dixon, S.J.; Lemberg, K.M.; Lamprecht, M.R.; Skouta, R.; Zaitsev, E.M.; Gleason, C.E.; Patel, D.N.; Bauer, A.J.; Cantley, A.M.; Yang, W.S.; et al. Ferroptosis: An iron-dependent form of nonapoptotic cell death. Cell 2012, 149, 1060-1072. [CrossRef]

76. Santos, J.S.D.; Cirino, J.P.G.; de Oliveira Carvalho, P.; Ortega, M.M. The Pharmacological Action of Kaempferol in Central Nervous System Diseases: A Review. Front. Pharmacol. 2021, 11, 2143-2158.

77. Wang, J.; Fang, X.; Ge, L.; Cao, F.; Zhao, L.; Wang, Z.; Xiao, W. Antitumor, antioxidant and anti-inflammatory activities of kaempferol and its corresponding glycosides and the enzymatic preparation of kaempferol. PLoS ONE 2018, 13, e0197563. [CrossRef]

78. Kashyap, D.; Sharma, A.; Tuli, H.S.; Sak, K.; Punia, S.; Mukherjee, T.K. Kaempferol-A dietary anticancer molecule with multiple mechanisms of action: Recent trends and advancements. J. Funct. Foods 2017, 30, 203-219. [CrossRef]

79. Wang, F.; Wang, L.; Qu, C.; Chen, L.; Geng, Y.; Cheng, C.; Yu, S.; Wang, D.; Yang, L.; Meng, Z.; et al. Kaempferol induces ROS-dependent apoptosis in pancreatic cancer cells via TGM2-mediated Akt/mTOR signaling. BMC Cancer 2021, $21,396$.

80. Zang, Y.; Zhang, D.; Yu, C.; Jin, C.; Igarashi, K. Antioxidant and hepatoprotective activity of kaempferol 3-O- $\beta$-D-(2, 6-di-O- $\alpha$-Lrhamnopyranosyl) galactopyronoside against carbon tetrachloride-induced liver injury in mice. Food Sci. Biotechnol. 2017, 26, 1071-1076. [CrossRef]

81. BinMowyna, M.N.; AlFaris, N.A. Kaempferol suppresses acetaminophen-induced liver damage by upregulation/activation of SIRT1. Pharm. Biol. 2021, 59, 146-156. [CrossRef] [PubMed]

82. Wang, M.; Sun, J.; Jiang, Z.; Xie, W.; Zhang, X. Hepatoprotective effect of kaempferol against alcoholic liver injury in mice. Am. J. Chin. Med. 2015, 43, 241-254. [CrossRef]

83. Chen, J.; Xuan, Y.H.; Luo, M.X.; Ni, X.G.; Ling, L.Q.; Hu, S.J.; Chen, J.Q.; Xu, J.Y.; Jiang, L.Y.; Si, W.Z.; et al. Kaempferol alleviates acute alcoholic liver injury in mice by regulating intestinal tight junction proteins and butyrate receptors and transporters. Toxicology 2020, 429, 152338. [CrossRef]

84. Fan, X.; Bai, J.; Hu, M.; Xu, Y.; Zhao, S.; Sun, Y.; Wang, B.; Hu, J.; Li, Y. Drug interaction study of flavonoids toward OATP1B1 and their 3D structure activity relationship analysis for predicting hepatoprotective effects. Toxicology 2020, 437, 152445. [CrossRef]

85. Singab, A.N.; Youssef, D.T.; Noaman, E.; Kotb, S. Hepatoprotective effect of flavonol glycosides rich fraction from egyptianVicia calcarata desf. Against CCI 4-induced liver damage in rats. Arch. Pharmacal Res. 2005, 28, 791-798. [CrossRef]

86. Cho, S.S.; Yang, J.H.; Seo, K.H.; Shin, S.M.; Park, E.Y.; Cho, S.S.; Jo, G.U.; Eo, J.H.; Park, J.S.; Oh, D.S.; et al. Cudrania Tricuspidata Extract and Its Major Constituents Inhibit Oxidative Stress-Induced Liver Injury. J. Med. Food 2019, 22, 602-613. [CrossRef] [PubMed]

87. Cai, F.F.; Bian, Y.Q.; Wu, R.; Sun, Y.; Chen, X.L.; Yang, M.D.; Zhang, Q.R.; Hu, Y.; Sun, M.Y.; Su, S.B. Yinchenhao decoction suppresses rat liver fibrosis involved in an apoptosis regulation mechanism based on network pharmacology and transcriptomic analysis. Biomed. Pharmacother. 2019, 114, 108863. [CrossRef] [PubMed]

88. Xu, T.; Huang, S.; Huang, Q.; Ming, Z.; Wang, M.; Li, R.; Zhao, Y. Kaempferol attenuates liver fibrosis by inhibiting activin receptor-like kinase 5. J. Cell. Mol. Med. 2019, 23, 6403-6410. [CrossRef] 
89. Zhang, Q.; Cheng, G.; Qiu, H.; Zhu, L.; Ren, Z.; Zhao, W.; Zhang, T.; Liu, L. The p53-inducible gene 3 involved in flavonoidinduced cytotoxicity through the reactive oxygen species-mediated mitochondrial apoptotic pathway in human hepatoma cells. Food Funct. 2015, 6, 1518-1525. [CrossRef] [PubMed]

90. Mylonis, I.; Lakka, A.; Tsakalof, A.; Simos, G. The dietary flavonoid kaempferol effectively inhibits HIF-1 activity and hepatoma cancer cell viability under hypoxic conditions. Biochem. Biophys. Res. Commun. 2010, 398, 74-78. [CrossRef]

91. Yusof, H.M.; Ng, M.S.; Lam, T.W.; Kassim, M.N. Hypolipidemic effects of quercetin and kaempferol in human hepatocellular carcinoma (HepG2) cells. Int. Food Res. J. 2018, 25, 241-245.

92. Wonganan, O.; He, Y.J.; Shen, X.F.; Wongkrajang, K.; Suksamrarn, A.; Zhang, G.L.; Wang, F. 6-Hydroxy-3-O-methyl-kaempferol 6-O-glucopyranoside potentiates the anti-proliferative effect of interferon $\alpha / \beta$ by promoting activation of the JAK/STAT signaling by inhibiting SOCS3 in hepatocellular carcinoma cells. Toxicol. Appl. Pharmacol. 2017, 336, 31-39. [CrossRef]

93. Du, Y.C.; Lai, L.; Zhang, H.; Zhong, F.R.; Cheng, H.L.; Qian, B.L.; Tan, P.; Xia, X.M.; Fu, W.G. Kaempferol from Penthorum chinense Pursh suppresses HMGB1/TLR4/NF- $\mathrm{kB}$ signaling and NLRP3 inflammasome activation in acetaminophen-induced hepatotoxicity. Food Funct. 2020, 11, 7925-7934. [CrossRef]

94. Shrivastava, S.; Uthra, C.; Reshi, M.; Shukla, S. Protective Role of Kaempferol against Acrylamide Intoxication. Free Radic. Antioxid. 2017, 7, 36-42. [CrossRef]

95. Lu, Y.; Shao, M.; Xiang, H.; Zheng, P.; Wu, T.; Ji, G. Integrative transcriptomics and metabolomics explore the mechanism of kaempferol on improving nonalcoholic steatohepatitis. Food Funct. 2020, 2020, 10058-10069. [CrossRef]

96. Wei, T.; Xiong, F.F.; Wang, S.D.; Wang, K.; Zhang, Y.Y.; Zhang, Q.H. Flavonoid ingredients of Ginkgo biloba leaf extract regulate lipid metabolism through Sp1-mediated carnitine palmitoyltranferase 1A up-regulation. J. Biomed. Sci. 2014, 21, 87. [CrossRef] [PubMed]

97. Kim, C.; Kim, B. Anti-cancer natural products and their bioactive compounds inducing ER stress-mediated apoptosis: A review. Nutrients 2018, 10, 1021. [CrossRef]

98. Mello, T.; Materozzi, M.; Galli, A. PPARs and mitochondrial metabolism: From NAFLD to HCC. PPAR Res. 2016, $2016,7403230$. [CrossRef]

99. Xiao, Y.B.; Cai, S.H.; Liu, L.L.; Yang, X.; Yun, J.P. Decreased expression of peroxisome proliferator-activated receptor alpha indicates unfavorable outcomes in hepatocellular carcinoma. Cancer Manag. Res. 2018, 10, 1781-1789. [CrossRef]

100. Chang, C.J.; Tzeng, T.F.; Liou, S.S.; Chang, Y.S.; Liu, I.M. bIntroduction. Planta Med. 2011, 77, 1876-1882. [CrossRef]

101. Raghunath, A.; Sundarraj, K.; Arfuso, F.; Sethi, G.; Perumal, E. Dysregulation of nrf2 in hepatocellular carcinoma: Role in cancer progression and chemoresistance. Cancers 2018, 10, 481. [CrossRef]

102. Shin, S.M.; Yang, J.H.; Ki, S.H. Role of the Nrf2-ARE pathway in liver diseases. Oxidative Med. Cell. Longev. 2013, $2013,763257$. [CrossRef] [PubMed]

103. Haque, E.; Karim, M.R.; Teeli, A.S.; Śmiech, M.; Leszczynski, P.; Winiarczyk, D.; Parvanov, E.D.; Atanasov, A.G.; Taniguchi, H. Molecular Mechanisms Underlying Hepatocellular Carcinoma Induction by Aberrant NRF2 Activation-Mediated Transcription Networks: Interaction of NRF2-KEAP1 Controls the Fate of Hepatocarcinogenesis. Int. J. Mol. Sci. 2020, 21, 5378. [CrossRef] [PubMed]

104. Sarwat, M.; Tuteja, N. Calnexin: A versatile calcium binding integral membrane chaperone of endoplasmic reticulum. Calcium Bind. Proteins 2007, 2, 36-50.

105. Schwarz, D.S.; Blower, M.D. The endoplasmic reticulum: Structure, function and response to cellular signaling. Cell. Mol. Life Sci. 2016, 73, 79-94. [CrossRef] [PubMed]

106. Mori, K. The unfolded protein response: The dawn of a new field. Proc. Japan Acad. Ser. B 2015, 91, 469-480. [CrossRef]

107. Sarwat, M.; Naqvi, A.R. Heterologous Expression of Rice Calnexin (OsCNX) Confers Drought Tolerance in Nicotiana tabacum. Mol. Biol. Rep. 2013, 40, 5451-5464. [CrossRef]

108. Maamoun, H.; Benameur, T.; Pintus, G.; Munusamy, S.; Agouni, A. Crosstalk between oxidative stress and endoplasmic reticulum (ER) stress in endothelial dysfunction and aberrant angiogenesis associated with diabetes: A focus on the protective roles of heme oxygenase (HO)-1. Front. Physiol. 2019, 10, 70. [CrossRef]

109. Bhattarai, K.R.; Riaz, T.A.; Kim, H.R.; Chae, H.J. The aftermath of the interplay between the endoplasmic reticulum stress response and redox signaling. Exp. Mol. Med. 2021, 53, 151-167. [CrossRef]

110. Creighton, T.E.; Hillson, D.A.; Freedman, R.B. Catalysis by protein-disulphide isomerase of the unfolding and refolding of proteins with disulphide bonds. J. Mol. Biol. 1980, 142, 43-62. [CrossRef]

111. Hwang, C.J.; Sinskey, A.J.; Lodish, H.F. Oxidized redox state of glutathione in the endoplasmic reticulum. Science 1992, 257, 1496-1502. [CrossRef]

112. Bhandary, B.; Marahatta, A.; Kim, H.R.; Chae, H.J. An involvement of oxidative stress in endoplasmic reticulum stress and its associated diseases. Int. J. Mol. Sci. 2013, 14, 434-456. [CrossRef] [PubMed]

113. Pollard, M.G.; Travers, K.J.; Weissman, J.S. Ero1p: A novel and ubiquitous protein with an essential role in oxidative protein folding in the endoplasmic reticulum. Mol. Cell 1998, 1, 171-182. [CrossRef]

114. Plaisance, V.; Brajkovic, S.; Tenenbaum, M.; Favre, D.; Ezanno, H.; Bonnefond, A.; Bonner, C.; Gmyr, V.; Kerr-Conte, J.; Gauthier, B.R.; et al. Endoplasmic reticulum stress links oxidative stress to impaired pancreatic beta-cell function caused by human oxidized LDL. PLoS ONE 2016, 11, e0163046. [CrossRef] 
115. Moslehi, A.; Komeili-movahed, T.; Moslehi, M. Antioxidant effects of amygdalin on tunicamycin-induced endoplasmic reticulum stress in the mice liver: Cross talk between endoplasmic reticulum stress and oxidative stress. J. Rep. Pharm. Sci. 2019, 8, 298-302. [CrossRef]

116. Zhang, B.; Li, M.; Zou, Y.; Guo, H.; Zhang, B.; Xia, C.; Zhang, H.; Yang, W.; Xu, C. NFkB/Orai1 facilitates endoplasmic reticulum stress by oxidative stress in the pathogenesis of non-alcoholic fatty liver disease. Front. Cell Dev. Biol. 2019, 7, 202-215. [CrossRef]

117. Riaz, T.A.; Junjappa, R.P.; Handigund, M.; Ferdous, J.; Kim, H.R.; Chae, H.J. Role of endoplasmic reticulum stress sensor ire1 $\alpha$ in cellular physiology, calcium, ROS signaling, and metaflammation. Cells 2020, 9, 1160. [CrossRef]

118. Chen, A.Y.; Chen, Y.C. A review of the dietary flavonoid, kaempferol on human health and cancer chemoprevention. Food Chem. 2013, 138, 2099-2107. [CrossRef] [PubMed]

119. Gong, J.; Wang, X.Z.; Wang, T.; Chen, J.J.; Xie, X.Y.; Hu, H.; Yu, F.; Liu, H.L.; Jiang, X.Y.; Fan, H.D. Molecular signal networks and regulating mechanisms of the unfolded protein response. J. Zhejiang Univ.-Sci. B 2017, 18. [CrossRef] [PubMed]

120. Yu, C.Y.; Hsu, Y.W.; Liao, C.L.; Lin, Y.L. Flavivirus infection activates the XBP1 pathway of the unfolded protein response to cope with endoplasmic reticulum stress. J. Virol. 2006, 80, 11868-11880. [CrossRef]

121. Sheng, X.; Nenseth, H.Z.; Qu, S.; Kuzu, O.F.; Frahnow, T.; Simon, L.; Greene, S.; Zeng, Q.; Fazli, L.; Rennie, P.S.; et al. IRE1 $\alpha$-XBP1s pathway promotes prostate cancer by activating c-MYC signaling. Nat. Commun. 2019, 10, 323. [CrossRef] [PubMed]

122. Preston, G.M.; Brodsky, J.L. The evolving role of ubiquitin modification in endoplasmic reticulum-associated degradation. Biochem. J. 2017, 474, 445-469. [CrossRef]

123. Shi, W.; Chen, Z.; Li, L.; Liu, H.; Zhang, R.; Cheng, Q.; Xu, D.; Wu, L. Unravel the molecular mechanism of XBP1 in regulating the biology of cancer cells. J. Cancer 2019, 10, 2035-2046. [CrossRef] [PubMed]

124. Gorman, A.M.; Healy, S.J.; Jäger, R.; Samali, A. Stress management at the ER: Regulators of ER stress-induced apoptosis. Pharmacol. Ther. 2012, 134, 306-316. [CrossRef]

125. Limonta, P.; Moretti, R.M.; Marzagalli, M.; Fontana, F.; Raimondi, M.; Marelli, M.M. Role of endoplasmic reticulum stress in the anticancer activity of natural compounds. Int. J. Mol. Sci. 2019, 20, 961. [CrossRef]

126. Liu, X.; Green, R.M. Endoplasmic reticulum stress and liver diseases. Liver Res. 2019, 3, 55-64. [CrossRef] [PubMed]

127. Walczak, A.; Gradzik, K.; Kabzinski, J.; Przybylowska-Sygut, K.; Majsterek, I. The role of the ER-induced UPR pathway and the efficacy of its inhibitors and inducers in the inhibition of tumor progression. Oxidative Med. Cell. Longev. 2019, $2019,5729710$. [CrossRef] [PubMed]

128. Hirsch, I.; Weiwad, M.; Prell, E.; Ferrari, D.M. ERp29 deficiency affects sensitivity to apoptosis via impairment of the ATF6-CHOP pathway of stress response. Apoptosis 2014, 19, 801-815. [CrossRef] [PubMed]

129. Galluzzi, L.; Vitale, I.; Aaronson, S.A.; Abrams, J.M.; Adam, D.; Agostinis, P.; Alnemri, E.S.; Altucci, L.; Amelio, I.; Andrews, D.W.; et al. Molecular mechanisms of cell death: Recommendations of the Nomenclature Committee on Cell Death 2018. Cell Death Differ. 2018, 25, 486-541. [CrossRef] [PubMed]

130. Rozpedek, W.; Pytel, D.; Mucha, B.; Leszczynska, H.; Diehl, J.A.; Majsterek, I. The role of the PERK/eIF2 $\alpha /$ ATF4/CHOP signaling pathway in tumor progression during endoplasmic reticulum stress. Curr. Mol. Med. 2016, 16, 533-544. [CrossRef]

131. Guo, H.; Ren, F.; Zhang, L.; Zhang, X.; Yang, R.; Xie, B.; Li, Z.; Hu, Z.; Duan, Z.; Zhang, J. Kaempferol induces apoptosis in HepG2 cells via activation of the endoplasmic reticulum stress pathway. Mol. Med. Rep. 2016, 13, 2791-2800. [CrossRef]

132. Wang, H.; Chen, L.; Zhang, X.; Xu, L.; Xie, B.; Shi, H.; Duan, Z.; Zhang, H.; Ren, F. Kaempferol protects mice from d-GalN/LPSinduced acute liver failure by regulating the ER stress-Grp78-CHOP signaling pathway. Biomed. Pharmacother. 2019, 111, 468-475. [CrossRef]

133. Niering, P.; Michels, G.; Wätjen, W.; Ohler, S.; Steffan, B.; Chovolou, Y.; Kampkötter, A.; Proksch, P.; Kahl, R. Protective and detrimental effects of kaempferol in rat H4IIE cells: Implication of oxidative stress and apoptosis. Toxicol. Appl. Pharmacol. 2005, 209, 114-1122. [CrossRef]

134. Hsu, J.Y.; Lin, H.H.; Chyau, C.C.; Wang, Z.H.; Chen, J.H. Aqueous Extract of Pepino Leaves Ameliorates Palmitic Acid-Induced Hepatocellular Lipotoxicity via Inhibition of Endoplasmic Reticulum Stress and Apoptosis. Antioxidants 2021, 10, 903. [CrossRef]

135. Glick, D.; Barth, S.; Macleod, K.F. Autophagy: Cellular and molecular mechanisms. J. Pathol. 2010, 221, 3-12. [CrossRef] [PubMed]

136. Li, X.; He, S.; Ma, B. Autophagy and autophagy-related proteins in cancer. Mol. Cancer 2020, 19, 12-28. [CrossRef]

137. Qi, Z.; Chen, L. Endoplasmic reticulum stress and autophagy. Autophagy Biol. Dis. 2019, 1206, $167-177$.

138. Budisan, L.; Gulei, D.; Jurj, A.; Braicu, C.; Zanoaga, O.; Cojocneanu, R.; Pop, L.; Raduly, L.; Barbat, A.; Moldovan, A.; et al. Inhibitory effect of CAPE and kaempferol in colon cancer cell lines-Possible implications in new therapeutic strategies. Int. J. Mol. Sci. 2019, 20, 1199. [CrossRef] [PubMed]

139. Ashrafizadeh, M.; Tavakol, S.; Ahmadi, Z.; Roomiani, S.; Mohammadinejad, R.; Samarghandian, S. Therapeutic effects of kaempferol affecting autophagy and endoplasmic reticulum stress. Phytother. Res. 2020, 34, 911-923. [CrossRef] [PubMed]

140. Han, B.; Yu, Y.Q.; Yang, Q.L.; Shen, C.Y.; Wang, X.J. Kaempferol induces autophagic cell death of hepatocellular carcinoma cells via activating AMPK signaling. Oncotarget. 2017, 8, 86227-86239. [CrossRef] [PubMed]

141. Xiang, H.; Shao, M.; Lu, Y.; Wang, J.; Wu, T.; Ji, G. Kaempferol Alleviates Steatosis and Inflammation during Early Non-Alcoholic Steatohepatitis Associated With Liver X Receptor $\alpha$-Lysophosphatidylcholine Acyltransferase 3 Signaling Pathway. Front. Pharmacol. 2021, 59, 146-156. 